\title{
Try to talk about the Construction of Practice Teaching system of Financial and Economics in higher Vocational Colleges
}

\author{
Wan Daili \\ Chongqing business vocational college \\ Chongqing, China
}

\begin{abstract}
Higher vocational education as a blend of the ordinary higher education and professional education model of vocational education, has a special development track. Finance is a professional, vocational important requirement for teaching, especially is very tall to the requirement of practical teaching. This paper briefly analyzes the current higher vocational practice teaching system construction of financial and economics in existence predicament, and mainly discussed the construction of effective path.
\end{abstract}

Keywords-higher vocational practice teaching system; Professional financial and economics; The construction of the path; The existing predicament

\section{THE INTRODUCTION}

Practice teaching is a feature of higher vocational education, mainly cultivate the practice of operating skills and comprehensive quality as the goal of teaching mode. Compared with the theoretical teaching, practical teaching development can be achieved by plan to organize students to attend face-to-face experiment and project practice, and other effective teaching methods to complete the internship positions. Higher vocational business professional practice teaching system is conditioned by various subjective and objective conditions, the relative lag, has its special difficulties. Therefore, build a scientific and perfect the practice teaching system, is the key to the current reform and innovation of financial and economics in higher vocational colleges.

\section{PRACTICE TEACHING SYSTEM OF FINANCIAL AND}

\section{ECONOMICS IN HIGHER VOCATIONAL COLLEGES}

\section{CONSTRUCT THE PRESENT PREDICAMENT}

Higher vocational practice teaching has always been to develop the first and the second industry of higher technology applied talents, such as engineering, agriculture and other professional, and is the third industry of financial and economics in a line management and service personnel, their difficulties in higher vocational practical teaching system construction and the difficulty is also relatively large ${ }^{[1]}$. First of all, teaching idea lag. Economics in more $\mathrm{Yu}$ Wenke, affected by traditional teaching concept is deeper, heavy theory, light has always been the main direction of teacher's teaching practice, the practice teaching system of conflicts effectively build. Second, finance professional teaching plan, teaching content, the curriculum is more used for ordinary higher education pattern, do not tally with the application characteristic of higher vocational colleges, theoretical teaching than important is higher than the proportion of practice teaching, build affected its practical teaching system of science. Again, the practice teaching system of teaching material is not sound. Effective development of practice teaching activities cannot leave the corresponding materials and data, can finance curriculum experiment (practice) materials in addition to the more rich and complete accounting course, it is difficult to find a public offering of other courses experimental textbooks (practice), the relevant teachers use handouts or only a temporary issue page scattered data in the form of organization to carry out the practice teaching, printing simple rough, optional the gender is strong, hard, complete specifications, system, influence the effect of the practice teaching. Finally, practice outside of limited. In general, social relevant departments need to business professionals, there were fewer than those engineering as a private company, financial talent is 3-5, and a factory for engineering will be hundreds of people. Economics in academic practice, therefore, is very difficult, the lack of effective internship opportunities, to improve the practical ability of students has brought greater difficulty. In addition, the economics in higher vocational colleges to teacher's personal accomplishment and high demand for practical operation ability, this gives the brought more pressure on the choice of teachers, scientific and perfect the practice teaching system construction difficulties.

\section{THE CONSTRUCTION OF HIGHER VOCATIONAL PRACTICE TEACHING SYSTEM OF FINANCIAL AND ECONOMICS IN PATH \\ A. To strengthen the construction of teaching material, strengthen the teaching theory}

Theoretical basis for teaching is an important premise to carry out the practice teaching, the construction of practical teaching system of financial and economics in higher vocational colleges need to start from the teaching material construction, strengthening theory teaching, to build perfect practice teaching system, to carry out the efficient preparation for practice teaching. In the teaching material construction of economics in higher vocational 
colleges, higher vocational colleges should not only absorb new achievements of vocational teaching time in China, the establishment of excellent teaching material, the advantages of the similar materials will also coordinate and electronic teaching materials, network teaching material, practice teaching materials play a good role in the teaching, such as to build scientific and perfect teaching system ${ }^{[2]}$. At the same time, teachers should according to the characteristics of the students of class, writing corresponding teaching materials, to fully consider the economics in the basis of students, increase the proportion of practice teaching in classroom, also according to the local regional characteristics, will be the teaching material content back to the students themselves life, improve the teaching effect.

\section{B. Perfect the teaching plan and content, establishing and perfecting the course system}

Higher vocational influenced by traditional teaching concept of financial and economics in deep, its teaching content and course system, teaching plan and so on are generally used for ordinary higher education mode, emphasized the systemic knowledge of transition, and ignore the application characteristics of higher vocational education. Therefore, to establish and improve the practical teaching system, must be to improve the teaching plan and content, and establish and improve the curriculum system. Must first to downplay the systematic knowledge, increase the proportion of practice teaching, and generally higher than $60 \%{ }^{[3]}$. According to the business separate professional training target practice teaching plan and syllabus, according to the practical teaching plan and syllabus, reasonable allocation to each link of practice teaching, practice teaching content arrangement, step by step to practice teaching goals and tasks of specific fulfil each in the practice teaching link, lets the student to master the necessary in the practical teaching, complete, skills and techniques of the system. Next, want to develop a plan of good skills training, the students need to achieve the technical standards of every school year, and the integrated skill examination at the end of each study. Finally, must carry on the "training leading" curriculum reform, widening on curriculum reform ${ }^{[4]}$. This is mainly in view of the practical teaching of financial and economics in less compared with engineering professional class, lack of training project take the measures.

\section{Implementation of diversified teaching methods, establishing and perfecting the teaching mode}

Teaching method is an important composition of teaching, theoretical teaching and practical teaching, the implementation of the diversification of positive and effective teaching methods to improve the teaching effect has a positive role in ${ }^{[5]}$. In the teaching of economics in higher vocational colleges, teachers can adopt case teaching, the exploratory teaching method, practice, project drive method, interactive teaching methods and teaching methods of social investigation. Treat more financial theoretical abstraction of knowledge, teachers can adopt case teaching method in teaching, help students better understand the problem, analyze problems, to think and solve problems. For some difficult point and hot topic, teachers can give students after class assignment, and group discussion in class the next day, so can not only arouse the enthusiasm of students' self-study, also can improve the students' team cooperation ability. In some weekends or holidays, teachers can organize and encourage students to actively participate in the social investigation, market research and other activities, from the actual society cultivate and arouse the practice ability of self.

\section{Increase the practical teaching base construction, \\ establish a "university-enterprise cooperation and} work-integrated learning" practical teaching system

"University-enterprise cooperation and work-integrated learning", is the current common practice teaching mode in higher vocational colleges, the students sent to outside companies to practice, to improve the practice ability of students is very beneficial. But students to the actual business of financial and economics in an internship or subject to many restrictions, which requires higher vocational college can give students complete the campus training opportunity. Practice teaching base is the basis of efficient practice teaching, is the basic facilities. In the construction of practice training bases in the school, to the goal of practice teaching, organizing form, such as included, combined with professional features of finance and economics and the social demand for building. In the process of building base need professional teachers with college equipment technical department to fully research and demonstration, or through the established team in the form of a joint research to solve [6]. For business professionals, colleges and universities need to establish a simulated bank training rooms, training rooms management, tax hall, simulation, simulation, insurance companies, the stock exchange will score post training base, audit practice base, etc. At the same time, higher vocational colleges should as far as possible with local relevant enterprises and institutions, such as Banks, securities companies, stock exchanges, such as strengthen communication and contact, as far as possible for internships for students.

\section{E. For training of teachers, to establish a high quality double team}

Teacher is an important link of practice teaching system of financial and economics in higher vocational colleges, its level of knowledge and practice ability directly affects the practice ability of students. Especially the professional financial and economics, financial work is extremely sensitive job, important in the position in enterprises and institutions, is easy to make mistakes. Teachers' quality of high and low, to students of financial and economics in future employment after values, professional ethics and so on all have influence. Therefore, to establish a high quality of double type teachers is extremely important. First of all, higher vocational colleges should take incentive measures to the existing full-time teachers encourage their active participation in various kinds of training and education activities, to obtain a higher practical experience, enhance self practical skills. At the same time, higher vocational colleges is to establish 
a good practical skills training for teachers of colleges and universities and education channels, such as base credentials the exercise, participate in vocational skills training, assessment, engaged in projects, especially some young teachers, to help the accumulation of experience and skills required to practice teaching, enhance its quality. Next, higher vocational colleges should according to the characteristics of economics in encourage and organize some backbone teachers of part-time work in a enterprise or business unit, engaged in some of the staff training, management consultants and so on work, encourage teachers can be improved in practice. Finally, higher vocational colleges can hire some high quality from financial institutions and enterprises, have rich experience and practical skills of talent to school lectures, training, and part-time lecturer.

\section{CONCLUSIONS}

In short, economics in higher vocational colleges is the important composition of higher vocational, compared the engineering professional practice teaching and also there is a big gap, need to constantly improve its teaching system. This is not only adapted to the trend of the development of the education in our country, also accord with the needs of higher vocational education reform and innovation of financial and economics in. In order to establish and improve scientific practice teaching system of financial and economics in higher vocational colleges, colleges and schools and teachers must strengthen the construction of teaching material, strengthening theory teaching; To perfect the teaching plan and content, establishing and perfecting the course system; To perfect the teaching plan and content, establishing and perfecting the course system; To strengthen the practice teaching base construction, establish a "university-enterprise cooperation and work-integrated learning" practical teaching system; To increase the training of teachers, to establish a high quality of the double team.

\section{REFERENCE}

[1] Ren Yan. Employment guidance of higher vocational college management and real estate valuation professional practice curriculum system construction [J]. Journal of shaanxi education (higher education), 2014 (8) : 26-27.

[2] Wu Lingfeng. Business vocational college practical teaching system of practice exploration $[\mathrm{J}]$. Journal of Inner Mongolia institute of finance and economics (comprehensive edition), 2012, 4 (6) : 27 to 28 .

[3] Denver, Hou Yanming. Higher vocational practice teaching material development of financial and economics in mechanism research [J]. Journal of economic and trade, north 2012, 05 (12) : 28 and 29.

[4] Hu Yingsen. Being flexible modular practice course system of higher vocational business under exploration $[\mathrm{J}]$. Journal of wuhan metallurgy management cadre institute, 2012 ((01) : 11-12.

[5] Colombia. Based on the factors of higher vocational professional teaching model in financial investment research $[\mathrm{J}]$. Journal of assets and financial administration career, 2014, 22 (02) : 13-14.

[6] Jiang Yaqin. Based on the collectivization school-running of higher vocational accounting professional group of connotation construction research $[\mathrm{J}]$. Journal of wuxi institute of commerce, 2015,09 (01) : 32-33. 